\title{
Non-Medicare Approved Hospital Transfusion Service
}

National Cancer Institute

\section{Source}

National Cancer Institute. Non-Medicare Approved Hospital Transfusion Service. NCI

Thesaurus. Code C133306.

A facility in compliance with the Clinical Laboratory Improvement Amendments Act of 1988 (42 U.S.C. 236a), but not Centers for Medicare and Medicaid Services compliant, that performs compatibility testing and transfusion of blood and blood components, but which neither routinely collects nor processes blood and blood components. 